\title{
TETRAZOLIUM TEST FOR EVALUATING TRITICALE SEED VIABILITY ${ }^{1}$
}

\author{
CAMILA RIBEIRO DE SOUZA², OSVALDO DE CASTRO OHLSON ${ }^{3}$, \\ MELÍCIA INGREDI ARAÚJO GAVAZZA4 ${ }^{4}$ MARISTELA PANOBIANCO ${ }^{5}$
}

\begin{abstract}
Freshly harvested triticale seeds are usually dormant, making the immediate evaluation of the physiological potential of seed lots difficult. We evaluated different triphenyl tetrazolium chloride (TTC) test methods for rapidly determining the viability of four seed lots of x.Triticosecale Wittmack cultivar IPR111. The test variables were: Preconditioning, (i) placing whole seeds between moistened paper towels or (ii) directly soaking the seeds in water, both procedures being conducted at $20^{\circ} \mathrm{C}$ for 18 hours; Post-conditioning seed preparation, (i) longitudinal bisection of the seed through the embryo with one half being stained and the other discarded or (ii) longitudinal bisection with both halves being stained; Staining for three and four hours, in the dark, with $0.1 \%, 0.5 \%$ or $1.0 \%(\mathrm{w} / \mathrm{v}$ ) TTC according to the preconditioning method described above, (i) both halves of each seed were placed on filter paper moistened with TTC and maintained at $40{ }^{\circ} \mathrm{C}$ or (ii) one half of each seed was immersed in $5 \mathrm{~mL}$ of TTC solution in a $100 \mathrm{~mL}$ glass beaker at $30^{\circ} \mathrm{C}$. The best results were obtained by preconditioning seeds between moistened paper towels at $20^{\circ} \mathrm{C}$ for 18 hours and staining on filter paper with $1.0 \%(\mathrm{w} / \mathrm{v}) \mathrm{TTC}$ for three hours at $40{ }^{\circ} \mathrm{C}$.
\end{abstract}

Index terms: germinability, seed analysis, X.Triticosecale Wittmack

\section{TESTE DE TETRAZÓLIO PARA AVALIAÇÃO DA VIABILIDADE DE SEMENTES DE TRITICALE}

\begin{abstract}
RESUMO - As sementes de triticale recém-colhidas apresentam normalmente dormência, dificultando a avaliação imediata do potencial fisiológico do lote. O trabalho teve por objetivo estudar diferentes procedimentos para a condução do teste de tetrazólio em sementes de triticale, a fim de determinar rapidamente a sua viabilidade. Foram utilizados quatro lotes de sementes da cultivar IPR111, testando as seguintes variáveis: a) pré-condicionamento entre folha de papel toalha umedecido e embebição direta em água a $20^{\circ} \mathrm{C}$ por 18 horas; b) dois tipos de preparo: corte longitudinal da semente através do embrião, com descarte de uma das metades e imersão da outra na solução de tetrazólio, a $30^{\circ} \mathrm{C}$, e corte com colocação das duas metades sobre papel filtro umedecido com a solução de tetrazólio, a $40^{\circ} \mathrm{C}$; c) coloração por 3 e 4 horas, sobre papel e imersão direta na solução; d) concentrações de solução de tetrazólio a $0,1 \%, 0,5 \%$ e $1,0 \%$. Pelos resultados obtidos concluiu-se que o teste de tetrazólio em sementes de triticale pode ser conduzido mediante embebição entre papel a $20{ }^{\circ} \mathrm{C}$ por 18 horas, coloração sobre papel por 3 horas, a $40^{\circ} \mathrm{C}$, na concentração de $1,0 \%$.
\end{abstract}

Termos para indexação: X. Triticoseale Witmack, germinação, análise de sementes.

${ }^{1}$ Submetido em 16/09/2009. Aceito para publicação 19/03/2010.

${ }^{2}$ Acadêmica do curso de Engenharia Agrônoma, UFPR, bolsista de iniciação científica da UFPR/TN, camilaribeiro@ufpr.br .

${ }^{3}$ Eng. Agr., M.Sc., Responsável Técnico do Laboratório de Análise de Sementes Oficial da Empresa Paranaense de Classificação de Produtos (CLASPAR), Rua João Américo de Oliveira, 330, CEP: 80035-060,
Curitiba-PR, E-mail: osvaldodecastro@claspar.pr.gov.br. ${ }^{4}$ Engenheira Agrônoma. E-mail: melgavazza@hotmail.com.

${ }^{5}$ Professora Adjunto, Departamento de Fitotecnia e Fitossanitarismo, UFPR, Rua dos Funcionários, 1540, CEP: 80035-050, Curitiba-PR, E-mail: maristela@ufpr.br. 


\section{INTRODUCTION}

Triticale (x.Triticosecale Wittmack), a hybrid winter cereal resulting from crossing wheat (Triticum aestivum) and rye (Secale cereale), has high commercial potential in some areas of Southern Brazil where it is principally used as an animal feedstuff and energy source in the period between maize (Zea mays) harvests (Brum et al., 1998), although it is also used as a feedstuff in the production of biscuits (cookies), breads and other dietary products for human consumption.

The evaluation of the physiological potential of seed has been included in internal quality control programs and, when conducted efficiently, allows identification of lots with a higher probability of adequately establishing in the field. Germination tests are commonly used for analyzing the physiological quality of seed lots but such tests can take from days to weeks or months for seeds exhibiting dormancy, this situation being undesirable because of the need to quickly identify problems and make rapid decisions to minimize possible damage.

Dormancy is an important resource for the survival of some seed-bearing species for which it constitutes a resistance mechanism operating under unfavorable environmental conditions during which it guarantees that germination only occurs when conditions are favorable for the reestablishment of metabolism (Marcos Filho, 2005). However, dormancy limits the evaluation of the physiological quality of seeds during germination testing and results in the need for methods for overcoming dormancy, although the currently used techniques are not always effective and can create difficulties for the analysts in distinguishing between dead and dormant seeds (Cícero, 1986). Brazilian official seed testing methods (Brasil, 1992) states that in germination tests for triticale seeds the final count should be made at eight days but, however, freshlycollected triticale seeds present dormancy, indicating the need for the development of rapid viability tests.

The triphenyl tetrazolium chloride (TTC) test is an important rapid seed viability test based on the activity of dehydrogenases that catalyze mitochondrial respiration. This test correlates seed viability with alteration in the color of viable plant tissue due to an oxidation-reduction reaction involving added TTC which is reduced to the stable non-diffusing red pigment formazon (França Neto, 1999), the presence of which indicates mitochondrial respiration and allows differentiation between normallystained and unstained or abnormally-stained tissue (Marcos
Filho, 2005). The TTC test has a series of advantages over standard germination tests, including the following: it is not affected by factors such as the presence of fungi that can alter the results of normal germination tests; the physical and physiological conditions of the seed embryo are the focus of the test; viability can be evaluated rapidly using cheap and simple equipment; different levels of viability can be assessed for some species, e.g. soybean and bean; and a diagnosis as to why the seeds have lost viability is sometimes possible (Delouche et al., 1976; França Neto, 1999).

The efficiency of the TTC test depends on the development of seed preconditioning, post-conditioning preparation and staining methods adapted for each species (Cervi and Mendonça, 2009). Methodologies for carrying out the TTC test are constantly being refined, with specific manuals being available for Zea mays (Dias and Barros, 1999), Gossypium hirsutum (Vieira and Von Pinho, 1999), Phaseolus vulgaris (Bhering et al., 1999), Arachis hypogaea (Bittencourt and Vieira, 1999) and Glycine max (France Neto et al., 1999). For seeds, the International Seed Testing Association (ISTA) method for triticale recommends pre-conditioning the seeds by immersion in water for 18 hours at $20{ }^{\circ} \mathrm{C}$, followed by transversely or longitudinally sectioning half the embryo and threequarters of the endosperm and staining by immersion in $1.0 \%(\mathrm{w} / \mathrm{v}) \mathrm{TTC}$ solution for three hours at $30{ }^{\circ} \mathrm{C}$ (ISTA, 2003). The Brazilian Rules for Seed Testing (Regras para Análise de Sementes (RAS); Brasil, 1992), however, only provides general information for carrying out the TTC test, with no specific conditions for triticale. We investigated the methodology of the TTC test for rapidly determining the viability of triticale seeds with a view to optimizing the test for use under Brazilian conditions.

\section{MATERIAL AND METHODS}

The seeds used in the tests were four lots of triticale (x.Triticosecale Wittmack) cultivar IPR111 from the 2008 crop. The lots were homogenized and separated into subsamples 215 seeds for each treatment and then stored kraft paper in packages at $14{ }^{\circ} \mathrm{C}$ and $50 \%$ relative humidity (RH). The experiments were carried out in July 2009 at the Official Seed Analysis Laboratory of the Paraná State Company for the Classification of Products (Laboratório de Análise de Sementes Oficial da Empresa Paranaense de Classificação de Produtos (CLASPAR), Curitiba, Paraná, Brazil. 
The initial humidity and percentage germination of each lot was determined by the Brazilian RAS method (Brasil, 1992): humidity by the oven set at $105 \pm 3{ }^{\circ} \mathrm{C}$ for $24 \mathrm{~h}$ with two $5 \mathrm{~g}$ sub-samples per lot, and germination by rolling the seeds in three layers of paper towel moistened with water equivalent to 2.5 times the mass of the paper towels and incubating the seeds at $20{ }^{\circ} \mathrm{C}$ for five days before calculating the number of plantlets according to the RAS methodology.

For the TTC test, four subsamples of 50 seeds were used for each treatment, the different combinations of treatments being described in the following paragraphs.

Preconditioning: (i) seed imbibition at $20^{\circ} \mathrm{C}$ for $18 \mathrm{~h}$ by wrapping the seeds in paper towels moistened with water equivalent to 2.5 times the mass of the paper; (ii) direct immersion for $18 \mathrm{~h}$ at $20{ }^{\circ} \mathrm{C}$ in $40 \mathrm{~mL}$ of water contained in a $100 \mathrm{~mL}$ glass beaker (ISTA, 2003). In both cases, the humidity of the seeds was determined after pre-conditioning in an oven set at $105 \pm 3{ }^{\circ} \mathrm{C}$ for 24 hs (Brasil, 1992).

Post-preconditioning seed preparation: (i) longitudinal bisection of the seed through the embryo with one half being stained and the other discarded (ISTA, 2003). For each subsample, one half of each seed section was immersed in $5 \mathrm{~mL}$ of $0.1 \%, 0.5 \%$ or $1.0 \%(\mathrm{w} / \mathrm{v})$ TTC solution in a $100 \mathrm{~mL}$ glass beaker at $30{ }^{\circ} \mathrm{C}$ for three and four hours until they reached the ideal color, after which they were removed, washed in running water and stored in water at $5{ }^{\circ} \mathrm{C}$ to $10{ }^{\circ} \mathrm{C}$ (ISTA, 2003); (ii) longitudinal bisection of the seed through the embryo with both halves being stained. For each subsample, both halves of each seed were placed on filter paper moistened with a quantity of $2,3,5-$ triphenyltetrazolium chloride (TTC) solution $(0.1 \%, 0.5 \%$ or $1.0 \%(\mathrm{w} / \mathrm{v})$ TTC) equivalent to 2.5 times the mass of the paper and maintained for three and four hours in the dark at $40{ }^{\circ} \mathrm{C}$, after which the seeds were stored on filter paper at 5 ${ }^{\circ} \mathrm{C}$ to $10^{\circ} \mathrm{C}$ until evaluation.

Viability was evaluated using a stereomicroscope and the recommendations of Grabe (1976) for cereals with small seeds. Seeds stained red were classified as viable, while improperly stained or unstained seeds were considered unviable, and the data obtained used to calculate the percentage of viable seeds.

The experimental design was completely randomized with four replicates. Means were compared using the Tukey test at the 5\% probability level and the Spearman model was used to investigate correlations between TTC test means and standard germination test means. The humidity results were not analyzed statistically.

\section{RESULTS AND DISCUSSION}

The initial seed moisture content values were similar for the four lots, varying between $12.7 \%$ to $13.7 \%$ (Table 1), a factor considered fundamental for standardizing viability tests and obtaining consistent results (Marcos Filho, 1999). The seed quality evaluation by the standard germination test (Table 1) separated the lots into high viability lots (denominated lots 1 and 2) and lower viability lots (denominated lots 3 and 4).

TABLE 1. Mean germination values and seed moisture content of four lots of triticale seeds.

\begin{tabular}{ccc}
\hline Lot & Germination (\%) & Moisture content $(\%)$ \\
\hline 1 & $83 \mathrm{a}$ & 12.7 \\
2 & $88 \mathrm{a}$ & 13.0 \\
3 & $73 \mathrm{~b}$ & 13.7 \\
4 & $70 \mathrm{~b}$ & 13.7 \\
\hline C.V. $(\%)$ & 4.56 & - \\
\hline
\end{tabular}

Means in the same column proceeded by the same letter do not differ significantly by the Tukey test at $\mathrm{p}=5 \%$. C.V. $=$ Coefficient of Variation.

Table 2 shows the TTC test results for preconditioning between paper and staining on filter paper. Staining for three hours was the most efficient time since this grouped the lots in a similar fashion to the standard germination test (Table 1), independent of the TTC concentration. The results indicate that the lowest TTC concentration $(0.1 \%)$ could be used in the test, except that with this concentration visualization of the essential structures and viability determination were difficult due to the weak staining produced. The ISTA (2003) TTC test method for triticale recommends a TTC concentration of $1.0 \%$, although our results suggest that $0.5 \%$ could also be used without affecting visualization of essential structures.

When the seeds were preconditioned between paper towels and stained by immersion in TTC solution (Table 2), three hours was again the most efficient staining time as measured by the fact that this staining time most efficiently separated the high viability seeds lots 1 and 2 and the lower viability lots 3 and 4 . However, these results were similar to those shown in Table 1 only for the $0.1 \%$ and $1.0 \%$ TTC. The results also indicate that when the seeds were hydrated to between $26 \%$ and $27 \%$ moisture content (Table 4 ) by wrapping in paper towel moistened with water equivalent to 2.5 times the mass of the paper there was no apparent inhibition of enzyme activity of the seeds. 
TABLE 2. Triphenyl tetrazolium chloride (TTC) test results for four lots of triticale seeds preconditioned between moist paper towels and stained on filter paper or by immersion using $0.1 \%, 0.5 \%$ or $1.0 \%$ TTC.

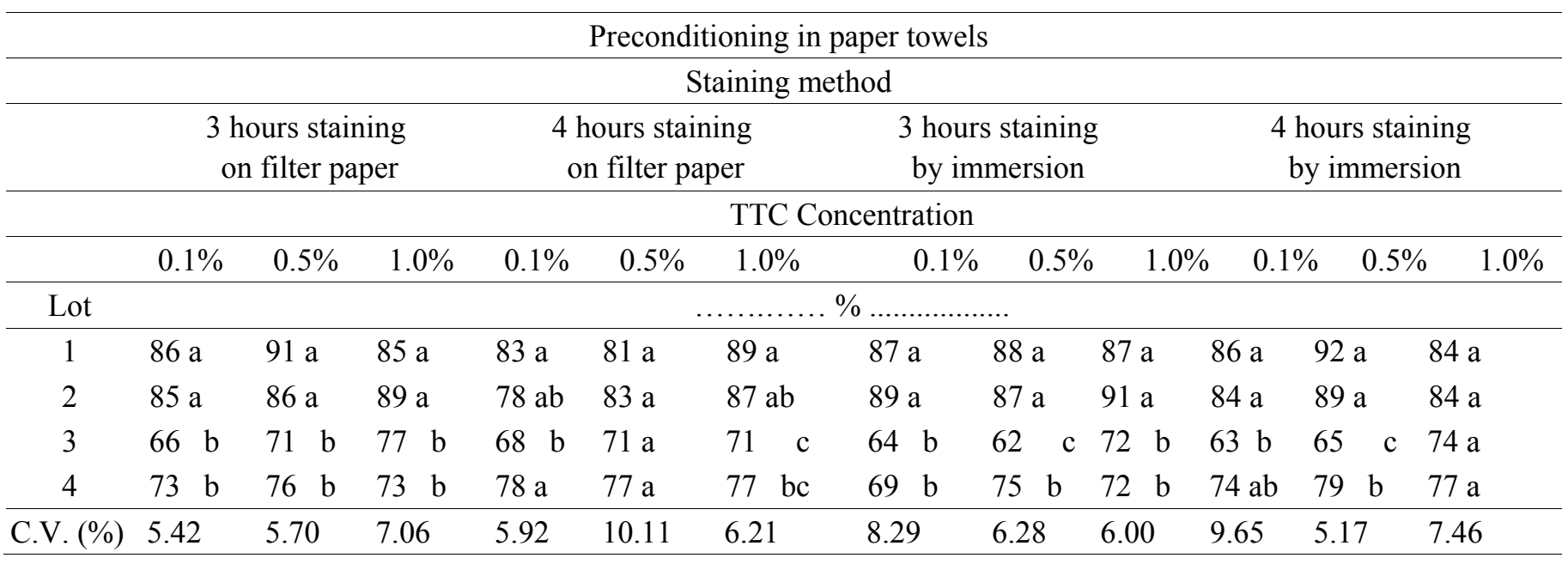

Means in the same column proceeded by the same letter do not differ significantly by the Tukey test at $\mathrm{p}=5 \%$. C.V. $=$ Coefficient of Variation.

Preconditioning softened the seeds, facilitated penetration of the TTC solution and activated enzymatic systems, resulting in more visible staining (Vieira and Von Pinho, 1999). The seed needs to reach a minimum humidity during preconditioning in order to activate the enzymatic system and guarantee staining.

Preconditioning by immersion, followed by staining both halves of each seed on filter paper was more efficient when staining was in $0.5 \%$ or $1.0 \%$ TTC for three hours or $1.0 \%$ TTC for four hours (Table 3). A short staining time, such as three hours, is important when rapid decisions have to be taken during viability screening by seed suppliers. Furthermore, economic savings accrue when using a lower TTC concentration, such as $0.5 \%$, which is still able to adequately visualize the tissue structure of the seeds. Reduced TTC concentration in the TTC test has also been suggested for other species, including $0.1 \%$ TTC for the Gossypium hirsutum (Vieira and Von Pinho, 1999) and $0.075 \%$ for Arachis hypogaea (Bittencourt and Vieira, 1999), Phaseolus vulgaris (Bhering et al., 1999), Zea mays (Dias and Barros, 1999) and Glycine max (France Neto et al, 1999).

TABLE 3. Triphenyl tetrazolium chloride (TTC) test results for four lots of triticale seeds preconditioned by immersion and stained on filter paper or by immersion using $0.1 \%, 0.5 \%$ or $1.0 \%$ TTC.

\begin{tabular}{|c|c|c|c|c|c|c|c|c|c|c|c|c|}
\hline \multicolumn{13}{|c|}{ Preconditioning by immersion } \\
\hline \multicolumn{13}{|c|}{ Staining method } \\
\hline & stainin & $\begin{array}{l}3 \text { hours } \\
\text { on filte }\end{array}$ & paper & stainir & $\begin{array}{l}4 \text { hours } \\
\text { on filter }\end{array}$ & paper & stainir & $\begin{array}{l}3 \text { hours } \\
\text { by imm }\end{array}$ & ersion & stainin & $\begin{array}{l}4 \text { hours } \\
\text { by } \mathrm{mm}\end{array}$ & ersion \\
\hline & \multicolumn{12}{|c|}{ TTC Concentration } \\
\hline & $0.1 \%$ & $0.5 \%$ & $1.0 \%$ & $0.1 \%$ & $0.5 \%$ & $1.0 \%$ & $0.1 \%$ & $0.5 \%$ & $1.0 \%$ & $0.1 \%$ & $0.5 \%$ & $1.0 \%$ \\
\hline Lot & \multicolumn{12}{|c|}{........... \% „.............. } \\
\hline 1 & $83 \mathrm{a}$ & $87 \mathrm{a}$ & $83 \mathrm{a}$ & $85 \mathrm{a}$ & $82 \mathrm{ab}$ & $88 \mathrm{a}$ & $85 \mathrm{a}$ & $88 \mathrm{a}$ & $83 \mathrm{a}$ & $87 \mathrm{a}$ & $85 \mathrm{a}$ & $82 \mathrm{a}$ \\
\hline 2 & $82 \mathrm{ab}$ & $92 \mathrm{a}$ & $86 \mathrm{a}$ & $84 \mathrm{a}$ & $86 \mathrm{a}$ & $81 \mathrm{a}$ & $87 \mathrm{a}$ & $82 \mathrm{ab}$ & $77 \mathrm{a}$ & $84 \mathrm{a}$ & $86 \mathrm{a}$ & $78 \mathrm{a}$ \\
\hline 3 & $68 \mathrm{c}$ & $67 \mathrm{~b}$ & $70 \mathrm{~b}$ & $70 \mathrm{~b}$ & 66 & $68 \mathrm{~b}$ & $71 \mathrm{~b}$ & $65 \mathrm{c}$ & $67 \mathrm{~b}$ & $70 \mathrm{~b}$ & $65 \mathrm{~b}$ & $74 \mathrm{a}$ \\
\hline 4 & $73 \mathrm{bc}$ & $70 \mathrm{~b}$ & $73 \mathrm{~b}$ & $79 \mathrm{ab}$ & $73 \mathrm{bc}$ & $75 \mathrm{~b}$ & $76 \mathrm{ab}$ & $74 \mathrm{bc}$ & $77 \mathrm{a}$ & $74 \mathrm{~b}$ & $74 \mathrm{ab}$ & $77 \mathrm{a}$ \\
\hline C.V. (\%) & 5.75 & 5.15 & 5.42 & 6.66 & 7.82 & 6.45 & 8.00 & 7.01 & 4.90 & 5.72 & 8.31 & 5.84 \\
\hline
\end{tabular}

Means in the same column proceeded by the same letter do not differ significantly by the Tukey test at $p=5 \%$. C.V. $=$ Coefficient of Variation. 
TABLE 4. Percentage seed moisture content (\%) of four lots of triticale seeds after preconditioning at $20{ }^{\circ} \mathrm{C}$ for 18 hours between moist paper towels or by immersion.

\begin{tabular}{ccc}
\hline & \multicolumn{2}{c}{ Preconditioning method } \\
\cline { 2 - 3 } Lot & Between paper towels & Immersion \\
\cline { 2 - 3 } & $\ldots \ldots \ldots \ldots \% \ldots \ldots \ldots$. \\
\hline 1 & 26.5 & 39.6 \\
2 & 27.4 & 40.4 \\
3 & 26.1 & 39.0 \\
4 & 26.0 & 40.5 \\
\hline
\end{tabular}

The ISTA (2003) method recommends preconditioning and staining by immersion, but Table 3 indicates that this methodology is not the most efficient or economical way to perform the TTC test for our triticale samples because it took four hours staining to separated the lots in a similar manner to the germination test (Table 1) and, furthermore, this only occurred with $0.1 \%$ TTC, which is not the most efficient concentration for assessing seed viability since this is best accomplished with $0.5 \%$ and $1.0 \%$ TTC.

Analysis of means showed that the most efficient methodologies for the rapid evaluation of the viability of our triticale seeds were preconditioning between paper towels (Table 2 ) or by immersion in water (Table 3 ), followed by staining on filter paper for 3 hours with $0.5 \%$ or $1.0 \%$ TTC. The Spearman correlation coefficients (Table 5) for the standard germination test and the TTC tests show that the highest correlation, significant at $p=1 \%$, occurred when the TTC protocol used preconditioning between paper towels followed by staining on filter paper for 3 hours with $1.0 \%$ TTC. However, preconditioning between paper towels followed by staining by immersion for 3 hours in $0.5 \%$ or $1.0 \%$ TTC was also significant, but only at $\mathrm{P}=5 \%$.

Preconditioning between paper towels and staining on filter paper makes it simple to perform the TTC test, especially considering visualization of the tissue structures of the seeds. This leads to a more rapid test and adds to the security of the interpretation of the test data. Staining both halves of each sectioned seed allowed better evaluation of the seed viability because it avoided the doubts which occur when only one half is evaluated, especially since it is difficult to cut the embryo exactly in the middle due to the small size of triticale seeds. This has also been commented on for seeds of the tropical forage grasses Brachiaria brizantha (Dias and Alves, 2008a) and Panicum maximum (Dias and Alves, 2008b).

TABLE 5. Spearman correlation coefficient ( $\rho)$ between the mean percentage germination values for four triticale seed lots as assessed by the standard germination test or staining with triphenyl tetrazolium chloride (TTC: $[0.1 \%],[0.5 \%]$ or $[1.0 \%])$ on filter paper or by immersion and after preconditioning between moist paper towels or by immersion.

\begin{tabular}{ccc}
\hline Treatments & \multicolumn{2}{c}{ Staining time } \\
\cline { 2 - 3 } [TTC concentration] & 3 hours & 4 hours \\
\cline { 2 - 3 } & Spearman correlation coefficient $(\rho)$ & Spearman correlation coefficient $(\rho)$ \\
\hline Filter paper method [0.1\%] & 0.60 & 0.35 \\
Filter paper method [0.5\%] & 0.60 & 0.80 \\
Filter paper method [1.0\%] & $1.00^{* *}$ & 0.60 \\
Immersion method [0.1\%] & 0.80 & 0.60 \\
Immersion method [0.5\%] & 0.60 & 0.60 \\
Immersion method [1.0\%] & $0.95^{*}$ & 0.75 \\
\hline & Preconditioning by immersion Staining method: & \\
\hline Filter paper method [0.1\%] & 0.60 & 0.80 \\
Filter paper method [0.5\%] & 0.80 & 0.60 \\
Filter paper method [1.0\%] & 0.80 & 0.60 \\
Immersion method [0.1\%] & 0.80 & 0.60 \\
Immersion method [0.5\%] & 0.60 & 0.80 \\
Immersion method [1.0\%] & 0.35 & 0.60 \\
\hline
\end{tabular}

*Significant by the t-test at $\mathrm{p}=5 \% * *$ Significant by the $\mathrm{t}$-test at $\mathrm{p}=1 \%$ 
The tissue structure of viable and unviable triticale seeds (both halves) preconditioned between paper towels and stained on filter paper moistened with TTC solution are shown in Figure 1. In the seeds of plants from the Poaceae, such as triticale, the most important areas for evaluation are the plumule, coleoptile, the central area of the scutellum, the radicular and the the seminal root system (Dias and Barros, 1999). The viable seeds in Figure 1A present a light carmine red staining in the vital areas due to reduced TTC while the nonviable seeds in Figure $1 \mathrm{~B}$ are white because the TTC was unreduced.

A

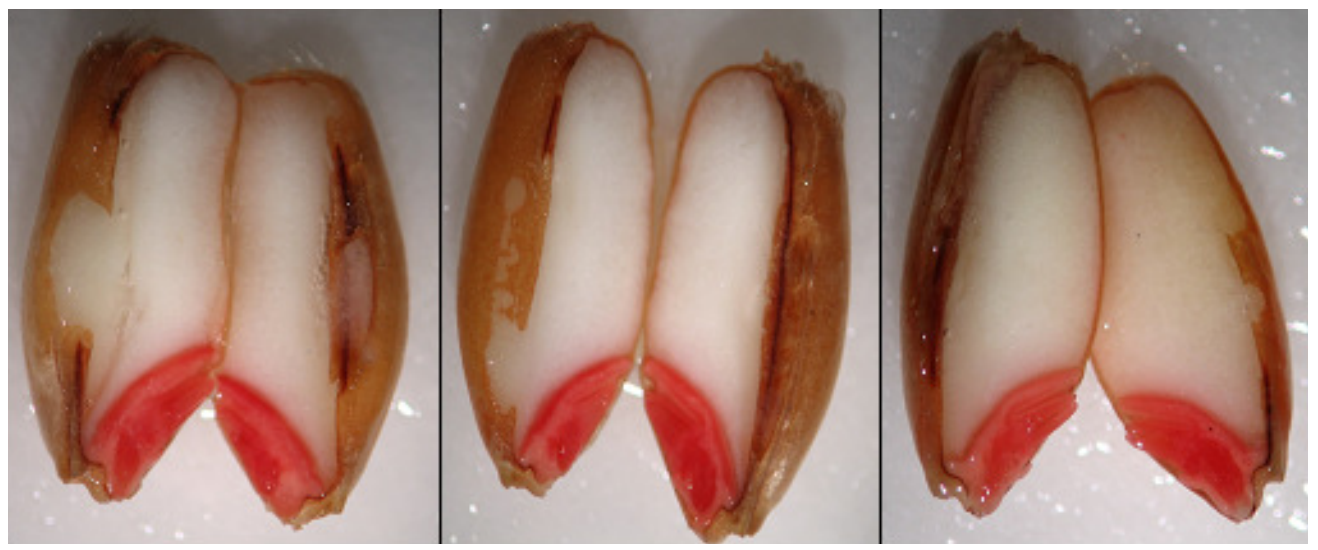

B

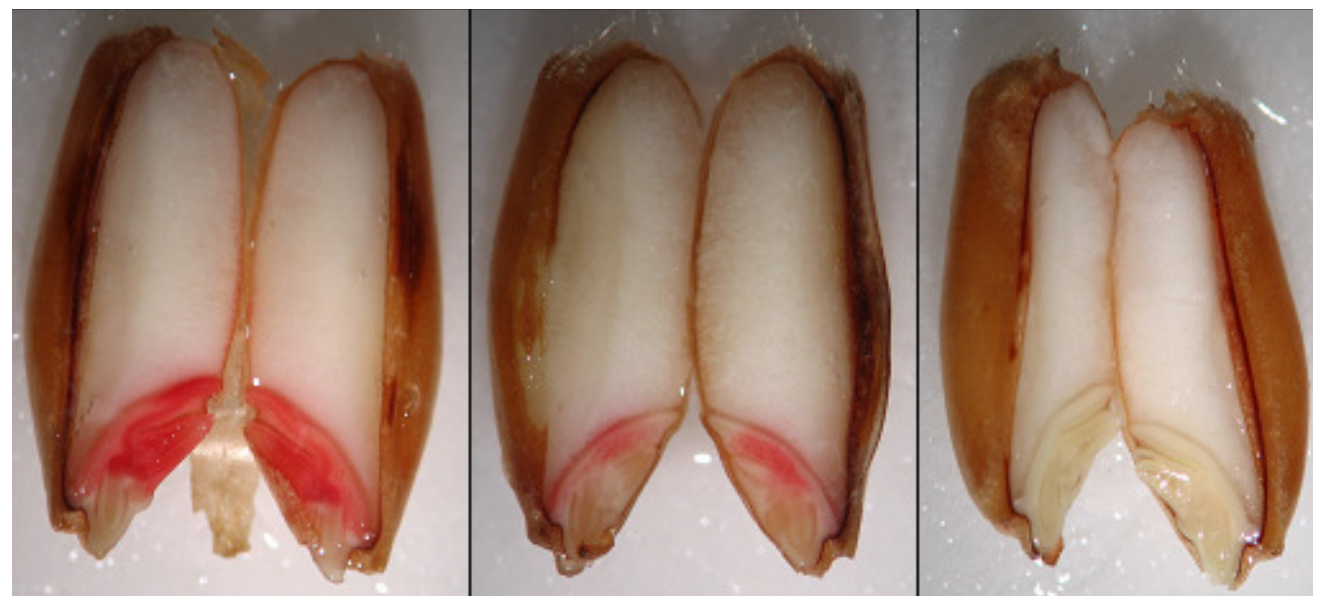

FIGURE 1. Triticale seeds preconditioned on paper towels for 18 hours at $20^{\circ} \mathrm{C}$ and then stained on filter paper with $1.0 \%$ triphenyl tetrazolium chloride (TTC) for three hours at $40{ }^{\circ} \mathrm{C}$. Figure $1 \mathrm{~A}$, viable seeds showing a light carmine red staining in the vital areas due to reduced TTC. Figure 1B, nonviable seeds are white because the TTC was unreduced.

\section{CONCLUSIONS}

The TTC test is an efficient method for the rapid evaluation of the viability of triticale seeds preconditioned on paper towels for 18 hours at $20{ }^{\circ} \mathrm{C}$ and then stained on filter paper with $1.0 \%$ TTC for three hours at $40{ }^{\circ} \mathrm{C}$.

\section{REFERENCES}

BHERING, M.C.; SILVA, R.F.; ALVARENGA, E.M.; DIAS, D.C.F.S. Metodologia do teste de tetrazólio em sementes de feijão. In: KRZYZANOWSKI, F.C., VIEIRA, R.D., FRANÇA NETO, J.B. (Ed.). Vigor de sementes: conceitos e testes. Londrina: ABRATES, 1999. cap.8.3, p.1-10.

BITTENCOURT, S.R.M.; VIEIRA, R.D. Metodologia do teste de tetrazólio em sementes de amendoim. In: KRZYZANOWSKI, F.C., VIEIRA, R.D., FRANÇA NETO, J.B. (Ed.). Vigor de sementes: conceitos e testes. Londrina: ABRATES, 1999. cap.8.2, p.1-8.

BRASIL. Ministério da Agricultura e Reforma Agrária. Secretaria Nacional de Defesa Agropecuária. Departamento 
Nacional de Defesa Vegetal. Coordenação de Laboratório Vegetal. Regras para análise de sementes. Brasília, DF, 1992. 365p.

BRUM, P.A.R.; ZANOTTO, D.L.; GUIDONE, A.L.; LIMA, G.J.M.M. Utilização do triticale em rações para frango de corte. Concórdia: Embrapa Suínos e Aves, 1998, 2p. (Instrução Técnica para o Avicultor, 2).

CERVI, F.; MENDONÇA, E.A.F. Adequação do teste de tetrazólio para sementes de algodoeiro. Revista Brasileira de Sementes, v.31, n.1, p.177-186, 2009.

CÍCERO, S.M. Dormência em sementes. In: CÍCERO, S.M.; MARCOS FILHO, J.; SILVA, W.R. Atualização em produção de sementes. Piracicaba: Fundação Cargill, 1986. p.41-73.

DELOUCHE, J.C.; STILL, T.W.;RASPET, M.;LIENHARD, M. O teste de tetrazólio para viabilidade da semente. Brasília, DF: AGIPLAN, 1976. 103p.

DIAS, M.C.L.L.; ALVES, S.J. Avaliação da viabilidade de sementes de Brachiaria brizantha (Hochst. Ex A. Rich) Stapf pelo teste de tetrazólio. Revista Brasileira de Sementes, v.30, n.3, p.145-151, 2008a.

DIAS, M.C.L.L.; ALVES, S.J. Avaliação da viabilidade de sementes de Panicum maximum Jacq pelo teste de tetrazólio.

Revista Brasileira de Sementes, v.30, n.3, p.152-158, 2008b.

DIAS, M.C.L.L.; BARROS, A.S.R. Metodologia do teste de tetrazólio em sementes de milho. In: KRZYZANOWSKI, F.C., VIEIRA, R.D., FRANÇA NETO, J.B. (Ed.). Vigor de sementes: conceitos e testes. Londrina: ABRATES, 1999. cap.8.4, p.1-10.

FRANÇA NETO, J.B. Teste de tetrazólio para determinação do vigor de sementes. In: KRZYZANOWSKI, F.C., VIEIRA, R.D., FRANÇA NETO, J.B. (Ed.). Vigor de sementes: conceitos e testes. Londrina: ABRATES, 1999. cap.8, p.1-7.

FRANÇA NETO, J.B.; KRZYZANOWSKI, F.C.; COSTA, N.P. Metodologia do teste de tetrazólio em sementes de soja. In: KRZYZANOWSKI, F.C., VIEIRA, R.D., FRANÇA NETO, J.B. (Ed.). Vigor de sementes: conceitos e testes. Londrina: ABRATES, 1999. cap.8.5, p.1-28.

GRABE, D.F. Manual do teste de tetrazólio em sementes. Brasília, DF: AGIPLAN, 1976.85p.

INTERNATIONAL SEED TESTING ASSOCIATION ISTA. In: ISTA Working Sheets on Tetrazolium Testing. Bassersdorf: ISTA, v.1, 2003. 171p.

MARCOS FILHO, J. Teste de envelhecimento acelerado. In: KRZYZANOWSKI, F.C., VIEIRA, R.D., FRANÇA NETO, J.B. (Ed.). Vigor de sementes: conceitos e testes. Londrina: ABRATES, 1999. cap.3, p.1-24.

MARCOS FILHO, J. Fisiologia de sementes de plantas cultivadas. Piracicaba: FEALQ, 1.ed. 2005.495p.

VIEIRA, M.G.G.C.; VON PINHO, E.V.R. Metodologia do teste de tetrazólio em sementes de algodão. In: KRZYZANOWSKI, F.C., VIEIRA, R.D., FRANÇA NETO, J.B. (Ed.). Vigor de sementes: conceitos e testes. Londrina: ABRATES, 1999. cap. 8.1, p.1-13. 